\title{
Aging of the Nigrostriatal Pathway in Humans
}

\author{
Donald B. Calne and R.F. Peppard
}

\begin{abstract}
Progressive degeneration of functionally related groups of neurons occurs in certain infective, toxic, nutritional and genetically determined neurological diseases. It also takes place in normal aging, and several of the regions that undergo selective decay with the passage of time seem to be the same target regions that are afflicted in degenerative disorders such as Parkinson's disease, Alzheimer's disease and amyotrophic lateral sclerosis (ALS). Infective etiology is relatively easy to exclude by a combination of immunological tests and transfer experiments. Genetic causation can be rendered unlikely when large kindreds are available for study. Nutritional deprivation and acute or subacute toxicity are accessible to explanation by examining the environment. The most difficult mechanism of pathogenesis to refute is chronic toxic damage, where the lesion may derive from long-term exposure to a relatively widespread noxious agent or agents. Variations in involvement of individuals within a population may stem from differing capacities to activate or inactivate a toxin. Inherent in this concept of etiology is recognition that compensatory potential within the central nervous system may contribute to prolonged existence of subclinical lesions so that a latent period may exist for several decades, between causal event and the onset of symptoms. Furthermore, progressive clinical deterioration may take place even though the cause may have been transient, many years before. The histological features associated with Parkinson's disease, Alzheimer's disease and ALS may be nonspecific indicators of neuronal "illness", there being a predilection for certain morphological markers to appear more frequently in particular circumstances and particular regions associated with the pathology of particular diseases.
\end{abstract}

RÉSUMÉ: Vieillissement du système nerveux et abiotrophie. Une dégénérescence progressive de groupes de neurones qui sont reliés entre eux par leur fonction survient dans certaines maladies neurologiques d'origine infectieuse, toxique, nutritionnelle ou génétique. Ce phénomène survient aussi dans le vieillissement normal et plusieurs régions qui subissent une dégénérescence sélective avec le temps semblent être les mêmes régions qui sont la cible de maladies dégénératives comme la maladie de Parkinson, la maladie d'Alzheimer et la SLA. Une étiologie infectieuse est relativement facile à exclure au moyen d'une combinaison d'épreuves immunologiques et d'essais de transmission de la maladie. On peut pratiquement éliminer une étiologie génétique quand on peut étudier des grandes familles. La carence nutritionnelle peut être soumise à l'analyse épidémiologique. La toxicité aigüe et subaigüe peut elle aussi généralement être expliquable en examinant l'environnement. Le mécanisme pathogénique le plus difficile à réfuter est l'intoxication chronique, le dommage pouvant alors résulter d'une exposition prolongée à un ou des agent(s) nocif(s) relativement répandu(s). Des variations dans le degré d'atteinte des individus au sein d'une même population peut provenir d'aptitudes différentes à activer ou à inactiver une toxine. Un élément inhérent à ce concept d'étiologie est la reconnaissance que le potentiel compensatoire dans le système nerveux central peut contribuer à l'existence à long terme de lésions subcliniques, de telle sorte qu'une période de latence entre l'évènement causal et le début des symptômes puisse s'étendre sur plusieurs décennies. De plus, une détérioration clinique progressive peut survenir, même si la cause peut avoir été transitoire, plusieurs années auparavant. Les caractéristiques histologiques associées à la maladie de Parkinson, à la maladie d'Alzheimer et à la SLA sont peut-être des indicateurs non spécifiques de “maladie" neuronale, certains marqueurs morphologiques ayant une prédilection pour apparaître plus fréquemment dans des circonstances particulières et des régions particulières, associées à la pathologie de maladies particulières.

Can. J. Neurol. Sci. 1987; 14:424-427

There has been recent interest in the possibility that certain degenerative diseases of late life, might derive from subclinical damage and subsequent normal age-related neuronal attrition.' In order to evaluate this hypothesis it is desirable to have a clear picture of what constitutes the normal spatial and temporal pattern of age-related neuronal loss, and how this compares with the dynamic pathology of degenerative disease.

\section{The Spatial Pattern of Aging}

For Parkinson's disease, Alzheimer's disease and motoneuron disease the primary site of neuronal decline coincides with areas of the central nervous system that appear to be selectively vulnerable to aging - the substantia nigra, the medial forebrain nucleus, and the motor neurons. While there is the common feature of these regions being particularly susceptible 
to pathological damage and the normal aging process, detailed comparison between the location of neuronal loss within these areas in senescence and disease is not possible because relevant observations are not available. The mechanism of selective neuronal loss in these regions is a matter of speculation. The most likely options include: (1) A metabolic mismatch between local tissue needs and vascular perfusion; this raises the question of whether there are unusual patterns of metabolism or vascularization in these areas; (2) infective susceptibility due to localized deficiency of the blood-brain barrier, or circumscribed immunological deficiencies; (3) toxic vulnerability; here there are many possibilities: (a) an inadequacy of the blood brain barrier (as for infections); (b) localized high active transport leading to accumulation of a toxin; (c) a high regional biochemical capacity for converting a protoxin to an active poison; (d) regional metabolic transformation specifically susceptible to a toxin; (e) a focal deficiency in the ability to remove or detoxify a noxious agent.

\section{The Temporal Pattern of Aging}

Information on the normal time course of regional age-related neuronal death is less complete and more controversial. Here we shall confine our attention to one site, the zona compacta of the substantia nigra. We shall review studies of the deterioration in various indices of the integrity of the nigrostriatal pathway in normal human aging, and compare this profile with what limited information is available for Parkinson's disease. The measures of nigrostriatal integrity fall into four categories: (1) enzymes involved in dopamine synthesis; (2) concentrations of dopamine; (3) numbers of dopamine receptors; (4) neuronal counts.

\section{(I) Enzymes involved in dopamine synthesis}

In their pioneering studies on this topic, the McGeers reported tyrosine hydroxylase and dopa decarboxylase levels declining with age. ${ }^{2}$ Their observations were based upon 28 post-mortem examinations of subjects without known neurological disease including four below the age of 15 years. Tyrosine hydroxylase in the caudate and putamen fall precipitously over the first 20 years of life and then decrease very slowly. Cote and Kremzner reported similar findings in 14 brains, though the fall was less precipitous below the age of 25 years, and tended to continue thereafter, albeit at a slower rate. ${ }^{3}$ They also stated that a similar trend occurred in the substantia nigra and the pattern was comparable for dopa decarboxylase.

The interpretation of alternations in enzyme concentrations in the brain is complex. Enzyme content is certainly a very indirect measure of neuronal integrity. In general, cells have more enzymes than they require, but the significance of the extent of this excess is not understood. The reported findings could be interpreted in terms of declining reserves in each neuron, rather than decreasing numbers of neurons.

\section{(2) Concentrations of dopamine}

In their classical paper on age-related loss of dopamine, Carlsson and Winblad reported a fairly linear decrement in striatal dopamine with advancing years. ${ }^{4}$ In a follow up from the same laboratory, Carlsson et al documented the dopamine concentration in 76 brains $;^{5}$ the pattern was beginning to look different, with relative stability followed by a profound decrease over the ages 60-90 years. Winblad (personal communication) has now extended this experience to over 100 subjects, and the trend of late fall off has been confirmed.

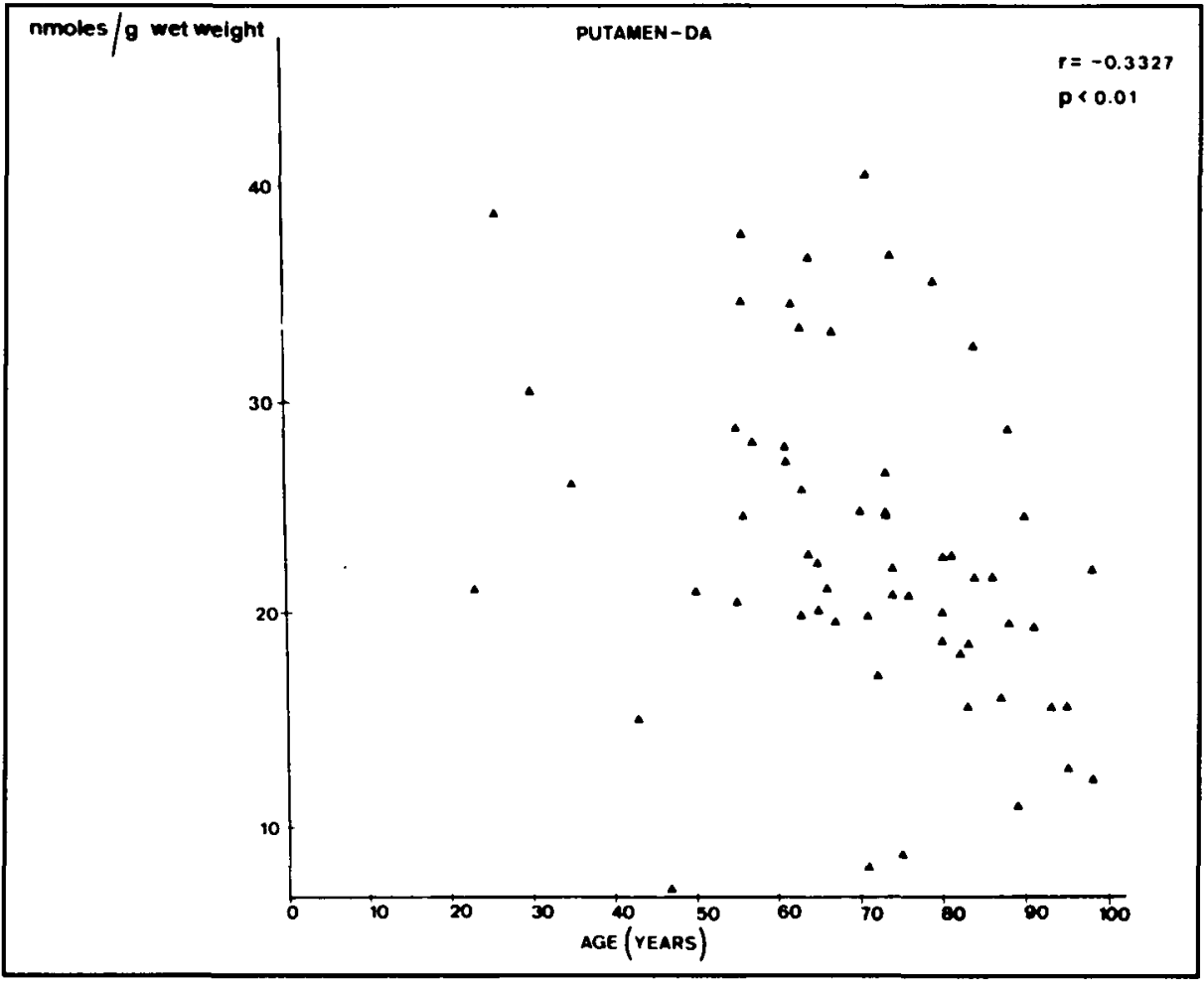

Figure 1 - The influence of age on the concentra. tion of dopamine in the putamen. (From A. Carlsson, P. Nyberg and B. Winblad ${ }^{5}$ ) 
As in the case of enzymes, the interpretation of quantitative changes in dopamine cannot readily be transposed to neuronal loss. The problem is similar to that for enzymes: transmitter concentration does not necessarily correlate with neuronal count.

\section{(3) Dopamine receptors}

Post-mortem studies on binding to dopamine receptors have been undertaken in 44 brains. ${ }^{6} \mathrm{~A}$ somewhat linear fall in spiperone binding was found in the substantia nigra and caudate, but not in the putamen. The fall occurred at a rate of about $50 \%$ over 70 years. A linear decrease of ADTN binding was also reported, somewhat more marked than that of spiperone binding.

Wong et al have investigated methyl spiperone striatal binding in vivo, employing positron emission tomography. ${ }^{7}$ Although the mathematical analysis of methylspiperone scans is at an early stage of development, the results did support the previous post-mortem observations. In 22 men, the fall was most marked before the age of 30 years, but in 22 women, the trend was towards equal levels throughout life.

The interpretation of age-related changes in striatal dopamine receptors is fraught with problems. Some dopamine receptors are postsynaptic and some are presynaptic, so it is extremely difficult to infer changes in nigral neurons from studies on dopamine receptors.

\section{(4) Neuronal counts}

There can be no doubt that direct morphometric studies provide the best evidence on the rate of nigrostriatal attrition. From counts on 13 brains, the McGeers found a fall in nigral neurons that was directly proportional to age, unlike the exponential pattern for tyrosine hydroxylase. There was a steady loss of neurons, with a $50 \%$ decline between the ages of 10 and 80 years ( $7 \%$ per decade), but observations after 60 years were limited to four brains.

A substantially larger group of brains has been studied by $\mathrm{Mann}^{8.9}$ and in particular the number of elderly subjects was much higher. They investigated four brains at approximately 15 years, 13 at approximately 65 years and 13 at approximately 84 years. They found a drop of $7 \%$ between the ages of 15 and 65 , with a subsequent fall of $21 \%$ between the ages of 65 and 84 years. This finding represents an acceleration from $1.4 \%$ per decade up to 65 years to $11 \%$ per decade after about 65 years, i.e. the rate of attrition increases eight fold in later life. These authors also studied nucleolar volume as an index of agerelated decline and the findings were very similar to the cell counts.

\section{Studies in Parkinson's disease}

There is only one paper ${ }^{10}$ in the literature that claims to provide information on the rate of loss of nigral cells in Parkinson's disease. This report compares the dopamine levels found postmortem in the caudate in control subjects over the ages of 50-90 years, and parkinsonian patients over the same age range. The parkinsonians were divided into two groups, one whose disease began at approximately 60 years and the other whose illness started at approximately 73 years. They conclude that the nigral neurons of parkinsonian patients decline more rapidly than age-matched controls, but from their results we consider that their patients were so unusual that they cannot be taken as a reasonable sample of subjects with Parkinson's disease. The anomalous features in their patients include:

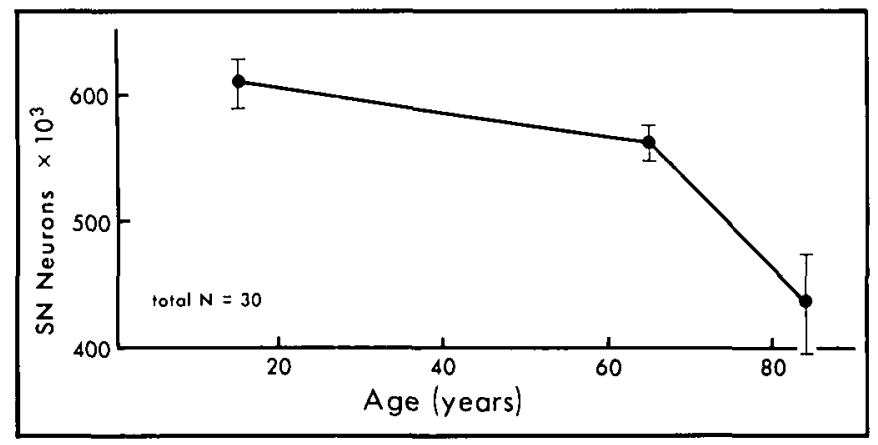

Figure 2 - The changes in the number of neurons in the substantia nigra with aging. (From D.M.A. Mann ${ }^{9}$ )

(1) The mean survival from onset of disease was five years.

(2) Survival was identical in the group whose disease started at 60 years and in the group that began at 73 years.

(3) The number of patients dying in the first five years of their disease was approximately the same as the number dying in the second five years. Assuming that severity correlates with duration of disease (as shown in all previous studies), this means that death was unrelated to the severity of their illness.

(4) Finally, since depletion of dopamine did correlate with duration of disease, we may infer that it bore no relation to the severity of the disease. This observation conflicts with the published literature involving considerably larger numbers of patients. ${ }^{11}$ For these reasons, we consider that more studies are desirable in this area. The advent of positron emission tomography should allow more meaningful sequential studies in the same individual.

\section{ConcLusion}

How may we summarize this diverse and sometimes apparently conflicting assembly of observations? There can be no doubt that the nigrostriatal pathway undergoes attrition over the course of aging, the salient question is whether neuronal loss is normally more rapid in early life or senescence. The most direct evidence is morphometric; while the McGeers reported a steady decline of $7 \%$ nigral neurons per decade, ${ }^{\prime}$ subsequent studies on a much larger group of subjects indicated a very small fall (1.4\% per decade) until late life, when the rate of decrement increased to over $10 \%$ per decade.

Of the indirect indices of nigrostriatal integrity, by far the largest group of observations came from analysis of post-mortem striatal dopamine in over 100 subjects. This work (Winblad, personal communication) leads to a conclusion entirely in accord with the morphometric studies; acceleration of attrition in later life.

We conclude that the major weight of current knowledge indicates an increase in normal age-related nigrostriatal degeneration in the elderly. This may perhaps be construed as offering some limited support for the hypothesis that Parkinson's disease might derive from early subclinical nigrostriatal damage, superimposed on a background of age-related neuronal death that accelerated over the period when symptoms most commonly appear and progress. 


\section{REFERENCES}

1. Calne DB, Eisen A, Stoessl AJ, et al. Alzheimer's disease, Parkinson's disease, and motorneuron disease: Abiotropic interaction between aging and environment? The Lancet 1986; 2: 1067-1070.

2. McGeer PL, McGeer E, Suzuki JS. Aging and extrapyramidal function. Arch Neurol 1977; 34: 33-35.

3. Cote LJ, Kremzner LT. Biochemical changes in normal aging in human brain. In: Mayeux R, Rosen WG, eds. Advances in Neurology. Volume 38. The dementias. Raven Press, New York, 1983; 19-30.

4. Carlsson A, Winblad B. Influence of age and time interval between death and autopsy on dopamine and 3-methoxytyramine levels in human basal ganglia. J Neural Transm 1976; 38: 271-276.

5. Carlsson A, Nyberg P, Winblad B. The influence of age and other factors on concentrations of monoamines in the human brain. In: Nyberg $\mathrm{P}$, ed. Brain monoamines in normal aging and dementia. Umea University Medical Dissertations, Sweden, 1984; 53-84.
6. Severson JA, Marcusson J, Winblad B, et al. Age-correlated loss of dopaminergic binding sites in human basal ganglia. J Neurochem 1982; 39: 1623-1631.

7. Wong DF, Wagner HN Jr, Dannals RF, et al. Effects of age on dopamine and serotonin receptors measured by positron tomography in the living human brain. Science 1984; 226: 1393-1396.

8. Mann DMA, Yates PO. Possible role of neuromelanin in the pathogenesis of Parkinson's disease. Mechanisms of Aging and Development 1983; 21: 193-203.

9. Mann DMA. Dopamine neurones of the vertebrate brain: Some aspects of anatomy and pathology. In: Winlow W, Markstein R, eds. The neurobiology of dopamine systems. Manchester University Press, Manchester, 1984; 87-103.

10. Riederer $\mathbf{P}$, Wuketich ST. Time course of nigrostriatal degeneration in Parkinson's disease. J Neural Transm 1976; 38: 277-301.

11. Bernheimer H, Birkmayer W, Hornykiewicz O, et al. Brain dopamine and the syndromes of Parkinson and Huntington. J Neurol Sci 1973; 20: 415-455. 